\title{
The Reconfiguration of Civil Society through Ethnic Communal Development
}

\author{
Walter Lalich \\ Macquarie University
}

\begin{abstract}
The large scale post-war migration impacted beyond the change of the demographic structure of Australia. The dynamics of migration impact is also felt beyond the immediate intent of particular ethnic communal developments in a place of settlement. Migration affected civil society in Australia too. Civil society is not a given good (Keane 1998, p.49) as it is also grounded in exogenous factors that are in this case identified as immigration effects. Cosmopolitan features of Australian cities have their foundations in fragmented ethnic voluntary collective actions. These social effects of post-war migration are contextualised through analysis of the diverse impacts and consequences of migrant collective acts undertaken to satisfy their own perceived needs through appropriation of communal places in Sydney. This article explores that part of the 'ethnic third sector' that relates to the activities of ethnic community organisations who established a place (building) where the religious, educational, recreational or welfare needs of immigrant communities in Australia were met. Utilising the concepts of bonding and bridging social capital to explore the social relations that developed in these migrant places and spaces, this article thus attempts to explore an important chapter in story of how post-war migrants have contributed to civil society in Australia.
\end{abstract}

\section{Introduction}

Australia has more immigrants of a greater diversity of ethnic background than most western societies today. Once in Australia, many immigrant groups have formed ethnic community associations, based on region of origin, religion, language or some other commonality. These ethnic community organisations, together with not-for profit organisations delivering migrantspecific programs and services, constitute the immigrant or ethnic component of Australian civil society organisations. Many ethnic community associations in Australia have an impact on the built-environment of Australia cities and towns through the buildings they construct, buy or lease in order to provide venues for the range of religious, educational, recreational and community activities that they engage in as part of Australia's 'ethnic third sector'. Indeed, the appropriation of communal places by fragmented ethnic collectives is among the key signifiers of the expanding Australian civil society in the past six decades of post-war Australian immigration. Migrant communities have thus actively shaped the built environment and social environment of their new society and the neighbourhoods in which they settle. This was often because they were either excluded from, or not really welcome in, the social spaces and places of White Anglo-Celtic Australia or because the existing collective spaces did not provide the religious instruction, sport, language instruction, social space or health service that new immigrant communities were seeking. They have thus undertaken steps to ameliorate their own situation and provide pales and spaces for their community to meet, gather, worship, play and learn. Through their own collective efforts migrants thus found a way to participate in civil society. They have done it through the establishment of institutions and organisations, establishing organisational structures, social and cultural resources, and developing or appropriating necessary communal places. Through this process numbers of participants, consumers and volunteers within Australia's ethnic communities expanded, leadership emerged and new employment opportunities were created. A sense of belonging in the Australian neighbourhoods where they settled was established.

Cosmopolitan Civil Societies Journal, Vol.2, No.1, 2010 ISSN: 1837-5391; http://utsescholarship.lib.uts.edu.au/epress/journals/index.php/mcs 
This article explores that part of the 'ethnic third sector' that relates to the activities of ethnic community organisations who established a place where the religious, educational, recreational or welfare needs of immigrant communities in Australia were met. Utilising the concepts of bonding and bridging social capital to explore the social relations that developed in these migrant places and spaces, this article thus attempts to explore an important chapter in story of how post-war migrants have contributed to civil society in Australia.

These are among the key indicators of migrant impact on civil society in Australia. This is a major social contribution of people who often arrive without anything but their culture and high hopes. Changing dynamics of ethnic social capital, solidarity and mutuality had a key role in this process. Initially developed to provide public spaces and places as an oasis for immigrant communities to meet (ie, as exclusive bonding social capital), these buildings over time have evolved into communal places where immigrant community members mingle with other members of their neighbourhood (bridging social capital), generating contacts wit, and providing services to, the broader community, an important but under-researched story of immigrant inclusion in the cultural, built and social environment through an expanded civil society.

\section{Ethnic communal development and civil society}

This contribution documents migrant institutional development through appropriation of ethnic communal places in Sydney, their scope, established functions, generated activities, social consequences and interaction (Jupp 2002, p. 28) ${ }^{1}$. Migrant grassroots non-profit associations developed in pursuit of the common good provide a dynamic impetus to the earlier established civil society patterns. Ethnic non-profit associations are located between migrants and their families and the rest of society, including the civil society, and, often in the relation to the rest of their own ethnic community. These mediating organisations add to the infrastructure of an expanding civil society and create the foundations of a cosmopolitan city. Post-war Sydney and Australian social development was greatly effected through appropriation of communal places that were perceived as necessary to satisfy migrant needs during settlement in an unknown and often hostile social environment.

The unique set of data generated from this sample of ethnic communal organisations is indicative of the confluence of migration and civil society. Data briefly document the process of appropriation itself and its impact on civil society through satisfaction of the immediate collectively perceived communal needs. Through the process of the appropriation of communal places, migrants actively participate in diverse communal activities, in communal life, generating a new sense of belonging in the place of settlement. Active involvement in communal life fosters migrants `individual and collective participation in civil society. This process generates communication flows across ethnic and social boundaries as well and expands migrants` role in a place of settlement. Diverse set of data presented in the second part of this contribution tell how civil society is impacted and reconfigured as a consequence of fragmented migrant collective appropriations of communal places that were deemed necessary to improve the quality of communal life during settlement in Sydney. Civil society is inevitably impacted by migrant participation in diverse communal activities that germinates a new sense of belonging and expands communication space beyond the community boundaries.

\footnotetext{
${ }^{1}$ By 1977 there were at least 2,000 ethnic organisations in Australia according to Jupp. There are several thousand ethnic community organisations in Sydney alone, and many rent and share communal places appropriated by other co-ethnic collectives or the mainstream institutions.
} 


\section{Civil Society}

The understanding of civil society implies voluntary participation by people having moral conviction in public life (Ahrne 1998), in this case of migrants who organise to satisfy their social and welfare needs. A contemporary comprehension of civil society is located in delineation of "multiple spheres and discourses" that are distinct from State authority and the market, but also from the immediate pursuit of self-interest (Jacobs 1998, Ehrenberg 1999, p.235, Cohen \& Arato 2003). Migrants` pursuit of personal self-interest is often interlinked with joint action towards satisfaction of a communal or group interest, irrespective of their character, that is political, religious, educational, leisure or welfare needs. Although differentiated, civil society is inter-related with the state and other spheres of social activity; its institutions and organisations are bound by the constitution, traditions, obligations and the laws the State lays down (Shils 2003).

Civil society as an emergent condition cannot be taken for granted, and is defined within the process of social differentiation and changing boundary relationships between spheres. Towards the end of the last century 'the question of possibility and demands of civil society have evidently been reinvigorated' (Tester 1992, pp.20-25) due to social changes in modernity, including the recognition of cultural diversity in urbanised world, intensive migration and consequent policy changes towards multiculturalism (Tester 1992, p. 33; Sandercock 1998, pp. 28-29, Sandercock 2003, pp.4, 8, 25-27 ). Under different conditions of migration, Vaclav Havel observes that civil society means a society that makes room for the richest possible self-structuring and the richest possible participation in public life (Elshtain 2001, p. 277). The implication is that civil society is a repository of sequences of human actions in response to the material, social, cultural and moral environment through which thousands of individual actions or "choices" may act to the benefit of a community as a whole (Jacobs 1998, p. 139, Elshtain 2001, 264).

\section{Associational life}

Civil society is expressed through collective action that is voluntary rather than compulsory and persuasive, rather than coercive (Walzer 2003, Ehrenberg 1999, p.218, Elshtain 2001, p. 263). It includes diverse organisations, from churches to voluntary civic associations established to support family, faith and secular interests. Such organisations are often established by migrants, ethnic groups, through their own collective action, and some are capable of appropriating their own facilities to satisfy a perceived communal need. To Ahrne (1998, pp. 85-86) and Anheier (2005, pp. 9, 58) modern civil society is the sum of diverse institutions and organisations which are considered to be the most natural organizational form of human interaction associated with civil society.

Associations are a major source of information and place of education, representation and alternative governance (Cohen \& Arato 2003, pp.42-45). Through a process of creation and access to collective resources, obligations are created, rights acquired and feelings of belonging and empowerment generated that enable sharing of resources and communication with the rest of society too. Civil society, considered as the outcome of a long and complex process of historical transformations (Keane 1998, p.50) reflects the multiplication and diversification of needs that appear during migration and settlement.

To satisfy their own perceived needs, migrants collectively make choices and create communal organisations. Migrants appropriate their own collective resources institutionalising solidarity and mutual assistance to gain access to otherwise unavailable 
resources. Through development of their own communal organisations, media ${ }^{2}$ and commercial enterprises migrants find their own place in the local social environment, making their voices heard while creating the foundations of pluralist society (Castles 2000, pp. 132, 139).

\section{Social capital}

Civil society is a product of social capital, of trust and solidarity, of mutuality. The expanding social capital, understood as a combination of norms, trusts and networks (Coleman 1990, pp. 300-307; Putnam 1993, p. 67; Bourdieu 1993, pp.32-33; Onyx \& Bullen 2000, pp. 105-109) among migrants (Portes 1995, pp. 12-16) is a key factor in the creation of associational life, in engagement for a common good and in access to the public sphere. Migration and settlement experience creates ties among people facing similar constraints. It generates bonding social capital (Putnam 2000, pp.22-23) that enables collective action, and is itself energized through development of associational life. Migrants create networks and find ways and means to respond to perceived needs and scarcity of resources. Out of informal groupings various communal organisations emerge, some capable of appropriating common goods necessary to satisfy a collectively perceived communal need.

The development and consumption of communal places of worship and leisure, schools and aged care by migrant collectives is made possible through enhanced bonding or exclusive social capital. Bonding capital is further intensified through the generated feeling of belonging and participation in diverse communal activities during settlement in Australian society defined by a sobriquet 'the quarantined culture' (Williams 1995, pp. 2-14), and in a city, Sydney, until recently considered as a homogeneous British outpost (Freestone 2000, p. 125) at the edge of the Pacific. The application of migrants`social capital, together with material and human capital, for socially productive purpose (Putnam 2000, p.22) made collective action and creation of communal places possible. Through the satisfaction of own their social needs, migrants`impact on civil society.

The final product of this development is in the emergence of bridging or inclusive social capital (Putnam 2000, p.22) that reaches towards the other segments of society and impacts on civil society beyond the ethnic and collective boundaries. Bridging and bonding social capital across the ethnic, generational and social divide are a prerequisite of social cohesion, a flourishing civil society and organisational sustainability. Through intensive interaction with their own social, human and material capital many migrant collectives made Sydney, and many other urban environments, a nicer place to live. This is reflected in beautiful buildings, a generated sense of belonging in a new environment, migrant participation in community life, in a multitude of experienced activities, expanded communication flows and in civil society dynamics.

\section{Australian social dynamics}

After a failure to attract large numbers of migrants from Britain, Australian authorities turned their sights to a war-ravaged continental Europe, to refugees, displaced persons and other potential migrants. This had dramatic impact on demographic, social and cultural structures in a society grounded on the transferred cultural and social institutions from the British Isles Aitkin 2005, pp. 2, 7). During the 1970s the White Australia policy was abandoned, and

\footnotetext{
2 There are over 100 non-English periodicals and 23 community and commercial radio and TV stations, besides SBS, registered currently by the Community Relations Commission for a Multicultural NSW (www.crc.nsw.gov.au/ethnic_media).
} 
patterns of migration expanded from refugees, chain migration and family reunion to permanent and temporary skilled migrants, and to new sources of migrants in Asia, Africa and Latin America. The number of inhabitants in Australia increased to 20 million in 2001 from 7.7 million in 1947. The continuously changing patterns of migration structure increased the share of inhabitants of non-English speaking background from 2.2 per cent of 1,7 million inhabitants to 23.4 percent of 4 million in the most popular destination, Sydney, during the same period (ABS 2001).

Australian society at the edge of modernity was least of all prepared for the diverse needs of new settlers who had to turn to themselves to solve most issues outside of employment and dealings with the government. Post-war settlers arrived in a country that was described by Horne (1978, p. 21) as having an indolent social climate, general prosperity and a philosophy of happiness, 'but life was dismal... with drink, sport, and money as the main diversions apart from their family life'. Australia was preoccupied with growth, not diversity (Rickard 1988, p. 227).

The prevailing exclusionary system was not tolerant of differences (Greig, Lewins \& White 2003, p. 188; Horne 1978, p. 18)) and public use of other languages 'marked the limits of xenophobia and hostility in the public realm' (Murphy 2000, p. 161). The 'momentous change' (Murphy 2000, p. 166) generated out of a large scale diversified immigration brought social and cultural changes, opened public space, and introduced new elements of civil society in a 'provincial nation' with the self-focused civil society organisations (Horne 1987, p. 114; Horne 1980, p. 65). The field of social interaction changed due to the immigration process and subsequent migrant collective actions expressed through communal development.

\section{Government interventions}

The major elements of the Australian vision of the state and its role in society was conceptualised until recently (Kelly 1992, pp. 1-2; Altman 2006, p. 18) around the issues of White Australia policy, welfare state based on industry protection and wage arbitration, state paternalism, and imperial benevolence. Public authorities had a paramount role, including as 'the creator of civil society' from the earliest days of modern settlement (Castles 1989, p. 42). Australia was considered to be a welfare society imbued with the egalitarian credo, therefore inclusive of a key principle of a modern civil society (Cohen \& Arato 2003, p. 285). Towards the end of the twentieth century these constitutive elements of social construction and sense of social cohesion mostly disappeared from the centre of public policy, as material issues and the individual privileges superseded the sense of social solidarity (MacKay 1993, p. 271; Aitkin 2005, p. 207; Altman 2006, p. 12, 27, 53, 77).

The welfare system in a 'lucky country' (Horne 1978, p. 217) based on protectionism, exclusion and white male domination ignored the marginalised categories well into the 1970's (Macintyre 1993, p. 321; Greig, Lewins \& White 2003, p. 180, 183). It was hardly a 'fair go' society for aborigines, to women (Horne 1970, p. 121; Rickard 1988, p. 229; MacKay 1993, p.24), and to migrants who were subject to assimilation pressures, as well as social and cultural marginalisation (Biskup 1982, Markus 1982, Weeks 2000). The civil society in Australia needed an impetus, and it came through migration and migrant communal development also.

Australian governments of both colours were a key driving force in fostering post-war migration and development of settlement policies and were, much more than the prevailing public opinion, positively disposed towards increasing and diversifying migration intake. The 
Department of Immigration established the Good Neighbour Movement in 1949 with an aim to support the settlement and welfare of New Australians and to circumvent local difficulties for its ambitious immigration programme (Lopez 2000, pp. 45, 95; Murphy 2000, pp. 162164). However, within the prevailing assimilation ideology, ignoring diverse migrant cultures and experiences (Jordens 1995, pp. 77-79), the movement lost its purpose as it communicated mostly with the British migrants and was terminated in 1978 in a new climate of multiculturalism.

Nevertheless, the attention eventually became focused on society`s responsibility towards new migrants, and, in 1971, the Minister of Immigration Lynch (1971, p. 16; 1970, p. 13) emphasised that migrants must 'become full and equal partners in our national life'. Among other changes, authorities started providing short term funding to migrant organisations from the late 1960s. Very soon in the 1970s authorities established diverse institutions such as the Ethnic Affairs Commissions, Ethnic Community Councils, and SBS Radio and Television service in state capitals with the intent to improve communication across cultural differences (Jupp 2002, pp. 80-81; Jordens 1995, p. 88).

However, due to cultural and social differences and settlement strains deprivations persisted. The findings by the Henderson Commission in 1975 (pp. 269-281) indicating the destitute position of many migrants corroborates other research findings (Jakubowicz 1989, Collins, J. 1991, Cox 1975, Jupp 1991, Jupp, 1986, Martin, 1975, Martin 1978). The disadvantageous position of most Southern Europe migrants who mostly did not benefit from the assisted passage scheme was further enhanced because of limited opportunities for English language tuition. This has dire consequence today for many ageing European migrants as many have difficulties in their communication with the rest of society (Collins \& Lalich 2004, pp. 29-31). Also, many elderly Asian migrants are in a similar situation as they encounter limited possibilities to learn English.

In such a situation many migrant collectives had to find their own solutions for some urgent social problems. They secured provision of necessary services through the appropriation of their own communal places. The situation prior to the acknowledgment of cultural diversity and introduction of multiculturalism is best described by the finding of the Fraser government- appointed Galbally Committee of Review of Post Arrival programs and Services to Migrants in 1978 that migrant organisations are '...the best channel for provision of support to ethnic communities' (Galbally 1978, p. 64). This is the best acknowledgment of the role of migrant communal organisations in society and of the migrant contribution to the development of civil society in Australia.

The inevitable social changes that found their expression in policy initiatives that were gradually introduced from the mid 1970s culminated in the recognition of cultural diversity and the introduction and adherence to multicultural policies. These developments affected the quality of life of migrants and broke the obvious cultural and communication gap. New policies, based on the principles of equity of access to public resources, maintenance of culture, self-help, creation of culture-specific services for migrants and consultation with clients (Jupp 2002, p. 80), became instrumental in opening a space for the inclusion of migrant communities in civil society too. Further changes of education, child and aged care policies (Hartley 1995, Marginson 1997, Brennan 1998) impacted development and maintenance of ethnic childcare, schools and aged care places too. Hence, the observation by Cope and Kalantzis (2000, pp. 80-83, 288, 339) that the watershed of civic pluralism was being reached towards the end of the last century, as an extension of participatory democracy 
based upon cultural democracy and expressed through multiculturalism, including the creation of multicultural citizenship.

\section{Migrant collective action in sydney and civil society}

Post-war Australian experience confirms observation by Walzer (2003, p.321) that civil society is sustained by small groups of people that are necessarily fragmented and localized as they are incorporated. Migrant voluntary collective action generated out of self-help, solidarity and mutuality at grass roots level is instrumental in expanding civil society through the creation of their own non-profit communal institutions. It enables collective appropriation of communal places that facilitate the everyday life of people who found themselves in a disadvantageous position during settlement. Migrants interact and strengthen the sense of responsibility as they create institutional elements of civil society through collective acts. Migration experience creates a habitus (Bourdieu 2000, p.148; 1990, p.52) that is advantageous for community development as the exigency eventually 'triggers action'.

Migrant needs, cultural differences, the inability and unwillingness of local introspective institutions to support settlement provides impetus for grass-roots collective actions. The appropriation of around 450 communal places by diverse ethnic organisations in Sydney to satisfy collectively perceived needs makes it possible to identify and quantify investment into appropriated common goods and its outcome, including participation and activities through which such participation is exercised in community life and in civil society. This experience is framed by the continental divide and the role of government in economic and social life (Pusey 1998, p.52; Greig, Lewins \& White 2003, p. 194; Aitkin 2005, p. 11).

Migrants participate in different forms during the appropriation, consumption and representation of communal places. Although volunteers are considered as a critical constraint in community organisations (Light 1972, p. 135, Drucker 1985, p. 182), claims that 'there are volunteers available according to the organisational need' and 'people help on request' indicate the high propensity of migrants to volunteer and that volunteering is a factor of the urgency (Lalich 2004, p.265). The acquisition and maintenance of appropriated communal places are made possible through voluntary collective commitment that differs within the organisational life cycle through provision of finance, material, labour and time.

The significance and the extent of migrant participation in ethnic communal organisations are difficult to estimate (Portes \& Bach 1985, p. 307; Light \& Bonacich 1991, p. 290). Through engagement for the common good, the otherwise under-utilised migrant human resources participate in fragmented collective endeavours to alleviate social problems. Voluntary labour was of key importance in the development of religious and leisure facilities in the early postwar decades, otherwise it would not have been possible. Today, nearly 18,000 volunteers actively engaged in ethnic communal places in Sydney represent just a segment of the local migrant volunteer participation. Besides volunteers, in these organisations are employed around 5,000 people with diverse skills who are not necessarily co-ethnics (Lalich 2004, p.281).

Most voluntary involvement is in places of worship (as much as 65.3 per cent), 20.0 per cent is in leisure, 3.2 per cent in education and 11.5 per cent in welfare organisations. This underlines the importance of religion to migrants and community life; educational organisations have a smaller participation rate due to their management by professional staff. Volunteers in welfare organisations include second generation well-educated professionals serving on boards, are indicative of the importance of these organisations beyond the 
generational change. The appropriation of material assets with estimated value of around six billion dollars in Sydney (Burnley 2006, p. 40) which generated annual income of at least 190 million dollars in 1997/98 (Lalich 2004) is the key outcome of interaction of human capital with the newly-created social capital at a time of exigency during settlement.

The significance of volunteering by 17,780 recorded volunteers is best illustrated with the application of data on average hours that Australians devote to voluntary work per week, which ranges from 0.70 to 3.3 hours (Lyons 1994, pp.37-38; Ironmonger 2000, p. 61). If it is assumed that they volunteer on average at least two hours per week, or around 100 hours a year, the total amounts to a million and three quarter volunteer hours in Sydney in 2000. Full appreciation would have to take into account that most of it is after work-hours and over the weekends, and at the expense of family time and alternative life opportunities.

\section{Foundations of a Cosmopolitan City}

Ethnic collectives appropriated a wide range of communal places dispersed across the Sydney metropolitan area. Migrants developed over half a million square metres of space where the needs of around two hundred thousand persons can be met at any given moment. Such development represents a major social value and is the best signifier of migrants' capability to satisfy collectively perceived communal needs through grassroots collective action.

The beginning of this process was located in a time when Sydney, according to Horne (1978, p.11), did not 'yet possess a really sophisticated city life, although it is beginning to imitate one'. The development presented in Table 1 shows the outcome of migrants' collective endeavours, fragmented due to cultural, linguistic, regional and ideological differences. It is identified in the creation of community capital that permeates communal life, developed sense of belonging, participation in diverse activities, and creation of new communication flows.

Table 1 Ethnic Communal Places: Developed Capacities, Sydney, 2000 Estimate (persons, sqm)

\begin{tabular}{|l|l|l|l|l|l|}
\hline Institutions & $\begin{array}{l}\text { Religious } \\
\text { (n206) }\end{array}$ & $\begin{array}{l}\text { Leisure }^{2} \\
\text { (n94) }\end{array}$ & $\begin{array}{l}\text { Education }^{3} \\
\text { (n39) }\end{array}$ & $\begin{array}{l}\text { Welfare }^{4} \\
\text { (n47) }\end{array}$ & $\begin{array}{l}\text { Total } \\
\text { (n386) }\end{array}$ \\
\hline Developed space $^{5}$ & 209,656 & 103,117 & 56,345 & 104,373 & 473,491 \\
\hline User place $^{6}$ & 119,819 & 48,081 & 10,751 & $2,270^{4}$ & 180,962 \\
\hline Regular users & 191,983 & 117,412 & $9,820^{7}$ & $2,197^{7}$ & $321,412^{7}$ \\
\hline
\end{tabular}

Source: Walter F. Lalich, Ethnic Community Capital: The development of ethnic social infrastructure in Sydney, Unpublished PhD dissertation, University of Technology, Sydney, 2004, p 207.

Notes: 1 . Any religious building, including halls and attached classrooms. 2. Social and sports clubs, community halls and centers. 3. Includes child-care facilities; some new schools were not filled to capacity. 4. Including retirement and nursing homes (40 units). 5. Square metres. 6 . Persons, excluding football stadium places. 7. Adjusted for volunteers and employees would be 11,568 and 6,002 persons or total of 326, 965 regular users.

These capacities were developed through the actions of often small groups that experienced intensive social capital formation that made possible their disposition towards joint action for a common purpose. Such collective acts create tangible referents in social space 'that buttress the meaning of experience and shape the character of reciprocity' (Fernandez-Kelly 1995, p.220). Table 2 shows this process during the post-war period with data divided into two subperiods: the first (1950-1980) roughly covers the earlier assimilation period that terminated with the landmark recognition of ethnic communal organisations by the Galbally Committee in 1978 (Galbally 1978, p. 64). The second period, from 1980, parallels the development of 
multicultural policies and provision of public financial support to ethnic organisations, primarily to schools, childcare and aged care.

Table 2. The Development of Ethnic Communal Places ${ }^{1}$ : Intensity of development, by type and period, Sydney, 1950-2000, Estimate (n=units)

\begin{tabular}{|l|l|l|l|l|l|}
\hline Periods & Religious $^{2}$ & Leisure $^{3}$ & Education $^{4}$ & Welfare $^{5}$ & Total \\
\hline $1950-1970$ & 28 & 12 & 2 & 6 & 48 \\
\hline $1961-1970$ & 31 & 15 & 5 & 6 & 57 \\
\hline $1971-1980$ & 31 & 21 & 11 & 4 & 67 \\
\hline Total 1950-1980 & 90 & 48 & 18 & 16 & 172 \\
\hline $1981-1990$ & 51 & 31 & 18 & 17 & 117 \\
\hline $1991-2000$ & 67 & 15 & 8 & 14 & 104 \\
\hline Total 1981-2000 & 118 & 46 & 26 & 31 & 221 \\
\hline Total 1950-2000 & 208 & 94 & 44 & 47 & 393 \\
\hline
\end{tabular}

Source: Walter F. Lalich, Ethnic Community Capital: The development of ethnic social infrastructure in Sydney, Unpublished PhD dissertation, University of Technology, Sydney, 2004, p 209.

Notes: 1. Data relate only to respondent organisations representing about 84 per cent of the total field. 2. Any religious building, including halls. 3 . Social and sports clubs, community halls and centres. 4 . Includes child-care facilities, but schools make $55 \%$ of development. 5 . Retirement and nursing homes make $77 \%$ of all development.

The apparent cultural differentiation in the post war years forced migrants` to secure badly needed religious and leisure facilities. The experienced cultural differences and inadequate existing public places were, alongside the assimilation pressures, major influences on the development of many clubs and places of worship. The development in the later years was influenced by increased investment capability, and migrant physical and social mobility, unlike in the earlier decades when the development was primarily influenced by diversification of continuous migration flows and persistence of cultural differences. The gradual stagnation of the development of leisure places in the 1990`s is indicative of social changes and the development of services in a cosmopolitan city capable of satisfying needs of new migrants. The expanding hospitality industry offset the growing needs of migrants, local inhabitants and tourists towards the end of century.

Consequently, many migrants from Asia, Africa and Latin America, instead of clubs, opened restaurants for which there was increased demand in the mainstream society too. Also, some ethnic clubs encountered new opportunities. Many Latin American migrants joined the leading Italian migrant social and sport club Marconi. The Sydney Croatian Club, located in Punchbowl, is often used by Lebanese and Macedonian migrants, while the restaurant in the Spanish Club in the CBD attracted many Asian students and tourists until recently when it closed down. Sydney, today, differs from the one at the mid-century, when European and Asian restaurants were a rarity.

The intensity of the appropriation of places of worship continued over the whole period due to the arrival of people with different religious background and the economic empowerment of many religious collectives. Religious organisations often provide language tuition, education and welfare services either at their own premises or through development of new facilities. New and larger places are being built, like the Greek Orthodox All Saints church in Belmore that stands beside the old wooden church, now a library and youth club. Furthermore, many 
churches and meeting places built earlier were appropriated and preserved as heritage and public places; the Croatian Catholic church St Anthony in Summer Hill was a Congregational church, while a former Masonic Hall in Ashfield is now a Chinese Buddhist and Taoist Temple.

The development of education and welfare facilities increased significantly in the second period, indicating changes in perceived social needs, expanding cultural diversity, increasing living standards and analogous policy changes. Multicultural policies and concurrent social policy changes have effected the development and daily financing of ethnic day schools, childcare and aged care services since the late 1970's onwards.

This communal development is a symbolic identifier of arrival, presence and permanency, but also a symbol of social success, created sense of belonging and affirmation of the transferred cultural heritage. Moreover, it is also a symbol of resistance (Pile \& Keith 1997, Routledge 1997, pp.70-71) to assimilation pressures and of social capital generated in a time of exigency applied towards enhanced communal benefit. The significance of many communal places appropriated by ethnic communities is in their higher level of expected sustainability in comparison to commercial edifices and home residencies. Many are expected to survive social and generational changes, and remain as key communication nodes of a cosmopolitan city (Lalich 2004, pp.324-330).

\section{Civil Society Expansion}

The significance of ethnic communal places in civil society is discussed through the generated sense of localized belonging and participation in communal activities that enable communication within collectives and across cultural and spatial boundaries. Ethnic communal places in cosmopolitan space identify the diversity of civil society, but, despite political changes, many ethnic organisations encounter problems either from neighbours or officials (Lyall 1990, Bouma, Daw \& Munawar 2001, Dunn 2001). Many ethnic organisations still experience expensive litigation in an attempt to proceed with development. Now, many locate in semi-industrial zones to escape prejudices and parking difficulties, as well as court cases, while making the best use of public transport for their ageing members.

\section{Participation}

The appropriation of ethnic communal places or capital was a strategy used by migrant collectives to satisfy community-perceived needs at the time of settlement, responding not only to exigency and crisis motives but also to the perceived future needs. Such motives differ due to culture and settlement experiences, and time of arrival, but determine the future consumption patterns. The consumption of these places could be defined by the density of a flow of people who use created resources through developed functions and organised activities. The flow of people is a prerequisite of civil society (Ahrne 1998, p. 94).

The undertaken appropriations as a consequence of 'functional imperatives' reflect 'the pressures of scarcity of time, opportunity and resources in the object situation' (Parsons, Shils \& Olds 1951, p. 177). The registered development in Sydney is focused on manifested or intended functional categories that have a crucial role for the 'continuous existence of a society' (Giddens 1997, p. 561-2). The established functions of migrant communal places define the intent of a particular collective, and secure conditions for continuous participation in communal life. 
Functions impact the activities or events that can be realised within the defined limits of a place. Appropriated places differ according to their function(s) and their ability to affect other systems (Katz \& Kahn 1966, p. 62), including other segments of civil society. A functional place can host unintended or latent activities too (Giddens 1997, p. 562) due to the everpresent scarcity of public and community space, and because life in a new social environment initiates a concentration of diverse activities. The established functions also define the symbolic representation of places and ethnic communities as well as identify their embeddedness in a place of settlement.

Although 40 per cent of respondent religious and 34 per cent of leisure communal places have only one function, some 34 per cent of religious and 37 per cent of leisure places have at least one additional function, and the rest more than three functions each. However, a recorded 206 religious organisations developed 197 additional functions, of which 37 per cent indicated education and 21 per cent a role as a community centre as their secondary function (Lalich 2004, pp. 306-308). Diversity of functions and appropriation of various roles makes many religious places key factors in community life and displays their vitality.

Places of leisure identified 105 additional functions indicating their functional diversity, besides their primary role as gathering places. Only 56 per cent indicate being a social club, while the rest indicate sports club, a place for recreation, and a community centre as their major function. Differences in their attributions represent a response to changes in society, in perceptions of community needs and the capability to produce a satisfactory response. Such changes emphasise culture, education, welfare and charity as key functions of these communal places appropriated during the 1990’s.

\section{Communal activities}

This development process enables unimpeded occurrence of relevant events or activities making a particular place a living one. Activities define the significance of a place to the particular collective as it is in the focus of everyday experience, however, access to and opportunity for activities would inevitably differ (Golledge \& Stimson 1997, p. 282). Places of worship and of leisure offer more opportunities and generate more activities than other categories. Respondent religious organisations identified over 3,000 activities or around fifteen different activities per unit, while leisure organisations identified at least 1770 activities or around nineteen per unit. Education and welfare organisations identified 305 and 465 registered activities respectively, or approximately ten per unit. Altogether, at least 5,540 identified activities enable participation and communication in diverse directions (Lalich 2004, pp.310-312). Some activities are organised even by outside bodies, not necessarily the co-ethnic.

It is essential to distinguish newly generated activities from generic ones that directly relate to the original function of a place. Generated activities make up more than half of all activities across categories indicating their importance in community life. Among generic activities are functional, administrative and social ones. The administrative activities enable the functioning of the community and the management of appropriated places, while the social ones include the opportunity for gatherings, meeting friends and social events. The third set of activities is clearly defined by the key function, such as the act of worship, participation in sport and looking after children.

All other activities are deemed to be unintended generated activities. Their intensity is much more dispersed, and are mostly identified as commercial, cultural, educational, entertainment, 
religious, welfare, and as age, gender and youth oriented activities. The diversity and intensity of experienced activities is of vital significance for the future of these organisations, as not all members display an equal degree of interest in participation in activities generated within and even out of a particular communal place. Although this development reflects feeling of sameness and internal group solidarity its impact is not limited to these places, as the creation of multiple activities originates opportunities for contacts across the cultural divide.

\section{Belonging}

It is argued by Gupta and Ferguson (1997, pp. 36, 39-41) that the sense of community refers both to a demarcated physical space and to clusters of interactions and that it could be highly 'localized' in a social sense. Migrants develop a sense of attachment to a specific communal place which they have appropriated, where they associate, create friendships and develop loyalties Deakin 2001, p. 60). In these communal places are embedded diverse phenomenological and functional attributes of significance to concerned communities. These identify a generated sense of belonging in a new environment which is the essence of civil society and citizenship.

A sense of place or belonging, and ascribed social and community values, is best identified by the richness of functional and relational signifiers attached to developed places, such as: home, hub of community, part of homeland, own place, ours, binding, belonging, island, mother, sacred (Lalich 2004, p. 320). Their social value is found in the understanding that it was 'worth getting' or 'having it' (Bond 1983, p. 1). Fortier describes appropriated physical spaces as 'migrant belongings' or terrains constituted for the creation of a collective sense of belonging (2000, p. 2). Such places enable a way of life in the new social environment and generate closer community relationships of sameness and togetherness.

The main reason behind the appropriation of communal places was to establish the conditions for creating a home for a transferred culture and a meeting place where people could meet without intimidation. This development facilitates the congregation of people besides established key religious, leisure, education and welfare functions. These communal places are neither inherited nor a product of a planned urban development, but reflect a collective response to perceived needs at the time of exigency in the encounter with social deprivation and indifference in a new social environment. In a dynamic city defined by spatial and social mobility the only relevant fixed and defined nodes for many citizens are their own communal places where they feel at home. These migrant appropriated communal places compensate for a home left behind, but as localized homes to transferred cultures they create key attributes of civil society and of a cosmopolitan city as well.

\section{Communication through sport}

The past discrepancy between demand and supply is best illustrated through the development of football as a major mode of recreation for many migrants and its acceptance as one of the major sports by the mainstream after a half a century of struggle. To post-war European migrants local sports were unfamiliar, unlike football to which they could relate, develop further, and organise and mobilise human and material resources around it. Football provided a vehicle for communication within and across the communities and with mainstream society. Sports clubs provided grounds for the affirmation of identity, community support, and are, as major social outlets (Cashman 1995, p. 163; Mosely et al. 1997, p.xv; Mosely 1997), key communication nodes in the Sydney metropolitan area. 
During this process, ethnic collectives established over 70 sports grounds; besides football grounds these include bocce, pelota and petanque grounds, and air rifle ranges. Some ethnic clubs underwent a process of expansion and modernisation to suit the needs of increased demand and membership needs, as 'the post-war generation of immigrants gave way to a new generation of Australian-born' (Hughes A. 1997, p. 109). Towards the end of last century football clubs were subject to pressures to de-ethnicise to improve possibilities for the game (Miller 1992, p. 109; Mosely 1997; Taylor \& Toohey 1997). Many clubs eventually changed names. In more recent years, governments supported the reorganization of the national competition on the basis of commercial franchises at the city level. Subsequently, the original leading national football clubs were relegated to the state level competitions with a detrimental effect on their futures.

Ethnic football had a major role in the creation of civil society and enhanced the sense of social cohesion and belonging despite severe structural constraints. Football created new social opportunities. Nearly half a century ago, Charlie Perkins, an early Aboriginal activist, played for Budapest and Croatia football clubs in Adelaide and later for the Pan-Hellenic in Sydney in the 1960s (Horne 1987, p. 74). The captain of the national football team during the 1970s, Johnny Warren, instead of joining other well established local football codes, associated with 'wogs, sheilas and poofters' as he aptly puts it on the cover page of his unofficial biography of football in Australia (Warren, Harper \& Whittington 2002). The sentiments changed radically in 2006 during the World Cup, when footballers acquired the status of national heroes. These expanding forms of cross-cultural communication stand in sharp contrast to the concurrent nostalgic parochial sentiments in a country whose identity is defined by sporting success manifested by the way in which media commentary on international sporting events is reduced to almost total concentration on the Australian competitors (Altman 2003, pp. 47-48).

Similarly, various other introduced leisure patterns and sports facilitate cross-cultural communication creating the foundations of a cosmopolitan city, generating conditions for communication across ethnic, cultural and spatial limits. The examples abound through joint use of sportsgrounds, halls and mixed team membership. Mixed crews of dragon boats clearly show that one among the major impediments to local civil society, the White Australia policy, has disappeared for good.

\section{Concluding Remarks}

The appropriation of communal places by fragmented ethnic collectives is among the key signifiers of the expanding Australian civil society. Migrant communities did not wait for opportunities to facilitate inclusion in society, and have undertaken steps to ameliorate their own situation amidst scarcity and diverse constraints. Through their own collective efforts migrants found a way to participate in civil society. They have done it through the establishment of institutions and organisations, despite existing cultural and linguistic differences, and limited resources. Migrants established organisational structures, social and cultural resources, and appropriated necessary communal places. Through this process numbers of participants, consumers and volunteers expanded, leadership emerged and new employment opportunities are created. A sense of belonging in a place of settlement was established. These are among the key indicators of migrant impact on civil society in Australia. Through active civic participation and generated bonding and bridging social capital, migrants contribute to civil society. 
The enhanced sense of community together with innumerable opportunities for social interaction and civic engagement generated by migrant direct participation in communal life has fundamental implications for democratic communities (Cohen \& Rogers 1995, p. 45; Elshtain \& Beem 2002, p. 37). It is a major social contribution of people who often arrive without anything but their culture and high hopes. Ethnic social capital, solidarity and mutuality had a key role in this process. Out of bonding, exclusive, social capital evolved communal places and bridging social capital, generating contacts with the rest of society and inclusion in the cultural and social environment through an expanded civil society.

\section{References}

Ahrne, G. 1998, 'Civil Society and Uncivil Organizations', in J. C. Alexander (ed), Real Civil Societies, Sage, London, pp 84-95.

Aitkin, D. 2005, What was it all for? The Reshaping of Australia, Allen and Unwin, Sydney. Altman, D. 2006, $51^{\text {st }}$ State?, Scribe Short Books, Carlton Vic.

Anheier, H. K. 2005, Nonprofit Organizations: Theory, Management Policy, Routledge, Oxford.

Australian Bureau of Statistics (ABS) 2001, Clib 2001 Census Statistics, Canberra.

Biskup, P. 1982, 'Aboriginal History’, in G. Osborne and W. F Mandle (eds), New History: Studying Australia Today, Allen \& Unwin, Sydney, pp11-31.

Bond, E. J. 1983, Reason and Value, Cambridge University Press, London.

Bouma, G., Daw, J. \& Munawar, R. 2001, 'Muslims Managing Religious Diversity', in A. Saeed \& A. Shahram (eds.), Muslim Communities in Australia, UNSW Press, Sydney, pp 53-72.

Bourdieu, P. 1990, The Logic of Practice, Stanford University Press, Stanford.

Bourdieu, P. 1993, Sociology in Question, Sage Publications, London.

Bourdieu, P. 2000, Pascalian Meditations, Polity Press, Cambridge.

Brennan, D. 1998, The Politics of Australian Child Care: Philanthropy to Feminism and Beyond, rev. ed, Cambridge University Press, Melbourne.

Burnley, I. 2006, 'Sydney's changing peoples: local expressions of diversity and difference', in R. Freestone, B.Randolph \& C. Butler-Bowdon (eds.), Talking about Sydney, UNSW Press, Sydney.

Cashman, R. 1995, Paradise of Sport: The Rise of Organised Sport in Australia, Oxford University Press, Melbourne.

Castles, G. F. 1989, Australian Public Policy and Economic Vulnerability, Allen \& Unwin, Sydney.

Castles, S. 2000, Ethnicity and Globalisation, Sage, London.

Cohen, J.L. and Arato,A. 2003, 'From Civil Society and Political Theory', in V. A. Hodgkinson \& M. W. Foley (eds), The Civil Society Reader, University of New England, Lebanon NH, pp 270-291.

Cohen, J. \& Rogers, J. 1995, 'Secondary Associations and Democratic Governance', in E. O. Wright (ed.), Associations and Democracy: The Real Utopias Project, Volume 1, Verso, London.

Coleman, J. S. 1990, Foundations of Social Theory, The Belknap Press of Harvard University Press, Cambridge Mass.

Collins, J. 1991, Migrant Hands in a Distant Land: Australia's Post-War Immigration, $2^{\text {nd }}$ ed, Sydney, Pluto Press.

Collins, J. and Lalich,W. 2004, Unsettling Migrant Settlement Services: Spotlight on the St George Region of Sydney, UTS/ACCORD Report, Sydney, 2004. 
Cope, B. \& Kalantzis, M. 2000, A place in the Sun: Re-creating the Australian Way of Life, Harper Collins, Sydney.

Cox, D. 1975, 'The role of ethnic groups in migrant welfare', in Welfare of Migrants, Australian Government Commission of Inquiry into Poverty, Australian Government Publishing Service, Canberra, pp. 5-144.

Deakin, N. 2001, In Search of Civil Society, Palgrave, Houndmills.

Drucker,P. F. 1985, Innovation and Entrepreneurship: Practices and Principles, Harper \& Row, New York.

Dunn, K. 2001, 'Representations of Islam in the Politics of Mosque Development in Sydney', Tijdschrift voor Economische en Soziale Geografie, vol. 92, no. 3, pp. 291-308.

Ehrenberg,J. 1999, Civil Society: The Critical History of an Idea, New York University Press, New York.

Elshtain,J. B. 2001, 'Civil Society, Religion and Formation of Citizens', in D. Ravitch \& J. P. Viteritti (eds), Making Good Citizens: Education and Civil Society, Yale University Press, New Haven.

Elshtain, J. B. \& Beem, C. 2002, 'Communities and Community: Critique and retrieval', in P. Alperson (ed.), Diversity and Community: An Interdisciplinary Reader, Blackwell, Oxford.

Fernandez-Kelly, P. 1995, 'Social and Cultural Capital in the Urban Ghetto: Implications for the Economic Sociology of Immigration', in A. Portes (ed.), The Economic Sociology of Immigration, Russell Sage Foundation, New York.

Fortier, A-M. 2000, Migrant Belongings: Memory, Space, Identity, Berg, Oxford.

Freestone, R. 2000, 'Planning Sydney: Historical trajectories and contemporary debates', in J. Connell (ed), Sydney: The Emergence of a World City, Oxford University Press, Melbourne.

Galbally, F. 1978, Migrant Services and Programs: Report of the Review of Post-Arrival Programs and Services for Migrants, Government of Australia, Australian Government Publishing Service, Canberra.

Giddens, A. 1997, Sociology, $3^{\text {rd }}$ ed, Polity Press, Cambidge.

Golledge, R. G. \& Stimson, R. J. 1997, Spatial Behavior: A Geographic Perspective, The Guildford Press, New York.

Greig, A., Lewins, F. \& White, 2003, K. Inequality in Australia, Cambridge University Press, Melbourne.

Gupta, A. \& Ferguson, J. 'Beyond "Culture": Space, Identity, and the Politics of Difference', in A. Gupta \& J. Ferguson (eds.), Culture, Power, Place: Explorations in Critical Anthropology, Duke University Press, Durham.

Hartley R. (ed) 1995, Families and Cultural Diversity in Australia, Allen \& Unwin /Australian Institute of Family Studies, Sydney.

Henderson,R. F. 1975, 'Poverty in Australia', Commission of Inquiry into Poverty, First Main Report, Australian Government Publishing Service (AGPS), Canberra, pp 269-281.

Horne, D. 1970, The Next Australia, Angus \& Robertson, Sydney.

Horne, D. 1978, The Lucky Country, Angus \& Robertson, Sydney.

Horne, D. 1980, Time of Hope: Australia 1966-72, Angus \& Robertson, Sydney.

Horne, D. 1987, 'The Lucky Country' Revisited, Dent, Melbourne.

Hughes, A. 'The Jewish Community. Sporting Immigrants: Sport and Ethnicity in Australia', in P. Mosely, R. Cashman, J. O’Hara, \& H. Weatherburn (eds.), Sporting Immigrants: Sport and Ethnicity in Australia, Walla Walla Press, Sydney.

Ironmonger, D. 2000, 'Measuring Volunteering in Economic Terms', in J. Warburton \& Melanie Oppenheimer (eds.), Volunteers and Volunteering, The Federation Press, Sydney. 
Jacobs, R.N. 1998, 'The Racial Discourse of Civil Society’, in J. C. Alexander (ed), Real Civil Societies, Sage, London, pp138-161.

Jakubowicz, A. 1989, 'Normalising aliens: The Australian Welfare State and the Control of Immigrant Settlement', in R. Kennedy (ed), Australian Welfare-Historical Sociology, MacMillan, Melbourne, pp 263-303.

Jordens, A-M. 1995, Redefining Australians: Immigration, citizenship \& national identity, Hale \& Iremonger, Sydney.

Jupp, J. 1986, Don't Settle for Less: Report of the Committee for Stage One of the Review of Migrant and Multicultural Programs and Services, Department of Immigration and Ethnic Affairs, Canberra.

Jupp, J. 1991, Immigration: Australian Retrospectives, Sydney University Press, Sydney, 1991.

Jupp, J. 2002, From White Australia to Woomera, Cambridge University Press, Cambridge.

Katz D.\& Kahn, R. L. 1966, The Social Psychology of Organizations, Wiley, New York.

Keane, J. 1998, Civil Society: Old Images, New Visions, Polity Press, Cambridge.

Kelly, P. 1992, The End of Certainty, Allen \& Unwin, Sydney.

Lalich, W. F. 2004, Ethnic Community Capital: The development of ethnic social infrastructure in Sydney, Unpublished PhD dissertation, University of Technology, Sydney, 2004.

Light, I. 1972, Ethnic Enterprise in America: Business and Welfare among Chinese, Japanese and Blacks, University of California Press, Berkeley.

Light, I. \& Bonacich, E. 1991, Immigrant Entrepreneurs: Koreans in Los Angeles 1965-1982, University of California Press, Berkeley.

Lopez, M. 2000, The Origins of Multiculturalism in Australian Politics 1945-1975, Melbourne University Press, Melbourne.

Lyall, G. 1990, 'Ethnic Buddhists in New South Wales', in A. W. Ata (ed.), Religion and Ethnic Identity: An Australian Study, vol. 3, Spectrum, Sydney, 1990, pp 6-30.

Lynch, P. 1970, People Make Nations, Department of Immigration, Canberra.

Lynch, P. 1971, The Evolution of a Policy, Department of Immigration, Canberra.

Lyons, M. 1994, Australia`s Nonprofit Sector, Working Paper Series, No.13, $2^{\text {nd }}$ ed, CACOM /UTS, Sydney.

Macintyre, S. 1993, The Oxford History of Australia. The Succeeding Age 1901-42, vol 4, Oxford University Press, Melbourne.

MacKay, H. 1993, Reinventing Australia: The mind and mood of Australia in the 90's,

Angus \&Robertson, Sydney.

Marginson, S. (ed) 1997, Educating Australia: Government, Economy and Citizen Since 1960, Cambridge University Press, Melbourne.

Markus, A. 1982, 'History of Post-War Immigration', in G. Osborne \& W.F. Mandle (eds), New History: Studying Australia Today, Allen \& Unwin, Sydney, pp 94-112.

Martin, J. 1975, 'The Economic Condition of Migrants', in Welfare of Migrants, Australian Government Commission of Inquiry into Poverty, Australian Government Publishing Service, Canberra, pp. 155-182.

Martin, J. 1978, The Migrant Presence, Allen \& Unwin, Sydney.

Miller, T. 1992, 'The unmarking of soccer: making a brand new subject', in T. Bennet, P. Buckridge, D. Carter \& C. Mercer (eds.), Celebrating the Nation: A critical study of Australia`s Bicentenary, Allen \& Unwin, Sydney.

Mosely, P. 1997, 'Soccer', in P. Mosely, R. Cashman, J. O’Hara, and H. Weatherburn (eds.), Sporting Immigrants: Sport and Ethnicity in Australia, Walla Walla Press, Sydney,1997, pp.155-173. 
Mosely, P., Cashman, R., O’Hara, J. \& Weatherburn, H. 1997, 'Introduction’ in P. Mosely, R. Cashman, J. O’Hara, and H. Weatherburn (eds.), Sporting Immigrants: Sport and Ethnicity in Australia, Walla Walla Press, Sydney.

Murphy, P. 2000, Imaging the Fifties: Private Sentiment and Political Culture in Menzies' Australia, Pluto, Sydney.

Onyx, J. \& Bullen, P. 2000, 'Sources of social capital’, in I. Winter (ed.), Social capital and Public Policy in Australia, Australian Institute of Family Studies, Melbourne.

Parsons, T., Shils, E. \& Olds, J. 1951, 'Values, Motives, and Systems of Action’, in T. Parsons \& E. Shils (eds.), Toward a General Theory of Action, Harper \& Row, New York.

Pile S and Keith, M. 1997, 'Introduction', in S. Pile and M. Keith (eds.), Geographies of Resistance, Routledge, London, pp. 1-16.

Portes, A. 1995, 'Economic Sociology and the Sociology of Immigration: A Conceptual Overview', in A. Portes (ed), The Economic Sociology of Immigration, Russell Sage Foundation, New York.

Portes, A. \& Bach, R. 1985, Latin Journey: Cuban and Mexican Immigrants in the United States, University of California Press, Berkeley.

Pusey, M. 1998, 'Between Economic Dissolution and the Return of Social: The Contest for Civil Society in Australia’, in C. J. Alexander (ed), Real Civil Societies, Sage, London, 1998.

Putnam, R. D. 2000, Bowling Alone, The Collapse and Revival of American Community, Simon \& Schuster, New York.

Putnam, R. D. 1993, Making Democracy Work, Princeton University Press, Princeton.

Rickard, J. 1988, Australia: A Cultural History, Longman, London.

Routledge, P. 1997, ‘A Spatiality of Resistance’, in S. Pile and M. Keith (eds.), Geographies of Resistance, Routledge, London.

Sandercock, L. 1998, Towards Cosmopolis, John Wiley, Chichester.

Sandercock, L. 2003, Cosmpolis II: Mongrel Cities of the $21^{\text {st }}$ Century, Continuum, London.

Shils, E. 2003, 'The Virtue of Civil Society', in V. A. Hodgkinson \& M. W. Foley (eds), The Civil Society Reader, University of New England, Lebanon NH, pp.292-305.

Spearritt, P. 2000, Sydney`s Century, UNSW Press, Sydney.

Taylor, T. \& Toohey, K. 1997, 'Ethnicity and Sport' in R. Lynch, T. Taylor \& K. Toohey, Sport and Ethnicity, UTS Centre for Leisure and Tourism Studies, Sydney, c1997, pp15-23.

Tester, K. 1992, Civil Society, Routledge, London.

Walzer, M. 2003, 'A Better Vision: The idea of Civil Society', in V. A. Hodgkinson \& M. W. Foley (eds), The Civil Society Reader, University Press of New England, Lebanon NH, pp 306-321.

Warren, J., Harper, A. \& Whittington, J. 2002, Sheilas, Wogs \& Poofters: An incomplete biography of Johnny Warren and soccer in Australia, Random House, Sydney.

Weeks, W. 2000, 'Women `s citizenship: Back into the family?’, in A. McMahon, J.Thompson \& C. Williams (eds.), Understanding the Australian Welfare State: Key documents and themes, Tertiary Books, Croydon Vic, pp 55-69.

Williams, J. F., 1995, The Quarantined Culture: Australian reactions to Modernism 19131939, Cambridge University Press, Melbourne. 